CONCLUSION

\title{
Epic Text and Context
}

Richard Martin, in his analysis of the act of speaking within the Iliad, says:

My central conclusion is that the Iliad takes shape as a poetic composition in precisely the same "speaking culture" that we see foregrounded in the stylized words of the poem's heroic speakers, especially those speeches designated as muthos, a word I redefine as "authoritative speech-act." The poet and hero are both "performers" in a traditional medium. The genre of muthos composing requires that its practitioners improve on previous performances and surpass them, by artfully manipulating traditional material in new combinations. In other words, within the speeches of the poem, we see that it is traditional to be spontaneous: no hero ever merely repeats; each recomposes the traditional text he performs, be it a boast, threat, command or story, in order to project his individual personality in the most convincing manner. I suggest that the "voice" of the poet is the product of the same traditional performance technique. ${ }^{1}$

In the Sìrat Banī Hiläl epic-singing tradition, no specific term such as muthos guides us to such an analysis, and the specific features of muthos composing are not those of "authoritative speech-acts" within the Arabic tradition. Yet our conclusions are remarkably similar. The clues in our analysis of Arabic oral epic performances have been rather a host of parallel frames, markers, and narrative devices which constantly correlate and negotiate the relationship between poets and heroes, of ten through the intermediary presence of a patron. The interpretation of Sirat Bani Hilal performances which we have built up through extended description xiv.

I. Richard P. Martin, The Language of Heroes: Speech and Performance in the "Iliad" (1989), 
of the tradition as it is found within a single village demonstrates the existence of a relationship, significantly similar to what Martin has proposed, between the speech of heroes within the epic and the speech of epic poets. Within the Hilāli tradition, however, we have the additional opportunity of observing the social reality of the Sirat Bani Hilāl epic singers and thence drawing further conclusions. As we have seen, the social reality of the al-Bakātūsh poets involves a distinctly negative position for the epic singer within the greater social hierarchy; in marked contrast to the poet's marginalized status in village society, however, are the moments of centrality, power, and "voice" he achieves in epic performance. This disjunctive persona has produced not only a fascinating process of deep self-identification with the epic tradition on the part of the poets, but has clearly, over generations, shaped and indeed constituted many aspects of the content of the epic itself-an epic tradition, as I have termed it, of heroic poets and poetic heroes.

The poets of al-Bakātūsh, however, possess an articulated counteridentity which they maintain in opposition to the negative stereotype of the Gypsy rabāb-poet held by the larger society. This subversive image of the poet as the eloquent, sharp-witted, and gracious "ur-Arab" is not, however, projected outward as a public expression of identity; it is an in-group ideal. In formulating this ideal the poets redeploy to their own ends many of the key features of the negative "Gypsy-poet" image: the suspect quality of the poet's glibness and his social criticisms in poetic performance become the most prized characteristics of the fașih (eloquent) "Arab"; the easy commingling of men and women in the poets' community becomes not the mark of "loose" morals but rather of ancient Arab custom and independence; the rabāb which signifies the "beggar-poets" to the larger society (it is the decisive marker of the professional poet in contrast to the nonprofessional reciter of Hilālī tales) becomes instead the respected tool of the epic-poet profession, one wielded proudly even by the famous heroes and warriors of old. The meeting point of the derogatory stereotype and this counteridentity is situated in the act of epic performance.

One distinctive narrative structure which reflects this meeting point involves the duplication of the epic performance within the epic: the creation of a complete parallel event of poet, patron, and participants. Here the poets of al-Bakātūsh habitually address issues of concern to them and to their audiences, issues at times as large as the status of poets in the world or the recent political problems in the village, at times as innocuous as the need for another round of tea or a few cigarettes for the guests. In their odes, and even more so in their prose asides to listeners, the poets deploy the ambiguity of the duplicated voice to comment upon and manipulate their own performance events. 
The transition from the realm of ordinary talk to that of epic discourse is accomplished in performance through a gradated process involving not only the gradual accrual of formal markings (rhyme, musical accompaniment, measured rhythm, regular verse length, and song) but the narrative necessity of intense emotional motivation on the part of the epic character. Moreover, each movement into the world of the epic echoes the frames of the sahra performance event as a whole-instrumental introduction, madị, mawwāl, spoken rhymed-prose preamble, blessings upon the Prophet, and finally, full arrival into the sira; the performance replicates itself over and over again in miniature. As a "way of speaking," the performances of heroes and of poets are constantly equated through the use of parallel frames and markers in an ultimately self-referential system.

The epic singers of al-Bakātūsh perform in a number of different contexts, each of which entails a different relationship between the performer, the patron of the event, other participants, and the content of the performance. Economic exigencies affect style, tone, and manner of performance; the setting is also a key to what degree of flexibility the poet displays toward the criticisms and comments of other participants. Villagers display overt antagonism to performances that they label "begging" or "vagrancy"; these are, however, precisely the performances that are fully under the control of the poet, performances where no patron is present and which may be initiated by the poet himself. The issue of control over the performances, and by extension over the tradition as a whole, appears to underlie villagers' attitudes in this domain. Within the seemingly paradoxical arrangement of having a marginal social group responsible for the performance of a tradition deemed of historical relevance and value to the whole community, the issue of when and for whom the poets are to speak is a contested one.

The epic sahra, a single context among many, is a social event that involves many different types of performance by both poet and other participants. Some forms of performance are conceptualized as such and formally labeled as genres; others are perceived by participants as informal activities unworthy of notice or of being recorded; all, however, act as conduits for social interaction within the event. Different forms of verbal art engage or disengage the participants in different ways, genres with varying degrees of "openness" or "closedness." The sira is presented as an independent story world, but one which audience members expect the poet to modulate in performance so as to comment upon the present; the hitat baladi on the other hand is created out of the very "stuff" of the present, using only the frame and some motifs of more independent material.

Quite often, threads of thought or sequences of associations develop 
out of the epic singing and the accompanying (often argumentative) evaluations of the performance: a wolf in the tale provokes the tale of a wolf, and from there we enter a discussion of wolves or other wild animals, then on to a debate about the personality of the epic character Diyāb 'Wolves'; later the poet picks up on our comments and returns them to us in narrative allusions within the epic.

Transformations, additions, and commentaries such as we examined in the last two chapters operate continually within Sìrat Banì Hilāl performances. Dramatic catalytic moments of interaction, however, occur less frequently-a few times an evening at most. These moments, though, are singled out by poets and audience members as particularly memorable, and they are retold and recalled far longer than any other aspect of the performance. I observed many times that once a performance had ended, listeners would discuss and comment upon many aspects of what they had just heard: the story, the characters, the poet's voice, his playing, his jokes, and so forth. Within a few hours, however, and certainly within a day or two, such commentaries had faded and participants no longer retained the aesthetic criticisms they had offered earlier. Instead, they remembered and discussed the social interaction within the performance, that is, the interplay that had taken place between the poet and the audience, or among members of the audience, especially those sparked by, or reflected in, the performed "text." If they could recite any of the poetry they had heard that night, it was most of ten the improvised asides and jokes, not passages from the epic! A single quatrain of improvised poetry sung in the village by Sayyid Hawwās nearly twenty years earlier was still in circulation in café conversations during my stay; only a fraction of those who quoted the lines could remember even which episode the poet had been singing on that occasion. Any single telling of a portion of the epic melted into previous tellings; the social events of a performance stood out as the individualizing, and thus the discussable, factors.

In al-Bakātūsh one attends a performance of epic first of all to participate in and share a social experience and only secondarily to attend to the "text." In essence, the social action within the event is, in this indigenous "reading," the text; the epic performance is but one of many possible contexts or backgrounds for the enactment and interaction of characters and personalities from daily life in the village. The sahra is a

2. This example of aesthetic criticism fading af ter a brief period of time while socially based recollections remain intact should cause us to reexamine Richard Bauman's claims, using historical reconstruction of performances that had taken place three decades earlier, that at the La Have Island general store, aesthetic criticism of storytelling did not exist, but only a general enjoyment of the social atmosphere. Bauman, "The La Have Island General Store: Sociability and Verbal Art in a Nova Scotia Community" (1972). 
stage for social interaction; though epic singing may form the focus of an evening's activities, the accompanying discussions, evaluations, arguments, and storytelling constitute, in a very real sense, the heart of the event. Here is a reading, then, in which the general terms of my research were reversed: the audience's text was my context, their context my text. In lengthy discussions, their "oral literary criticism" constantly slipped away from my own projected focus on the epic poem, to a view point from which the location of the epic as the absolute center of the social "context" could no longer be maintained. As a researcher interested in the processes of performance, I could well locate my "text" within the boundaries of the epic poem, and for historical and literary purposes might continue to do so; were I, however, concerned also to understand how that "text" signifies, how it is received by its patrons and audiences as meaningful, I should also have to reverse my analysis and explore the performance of epic poetry as a "context," allowing for social meanings not "present" within the epic. The act of locating and defining "text," choosing a focus, thus becomes the crucial analytic act, yet the more we press the boundaries, the more fluid they appear to become.

In seeking reactions to and interpretations of the epic, I found again and again that I was listening to evaluations not of an individual performance or event, but of larger social patterns and of the epic as a symbolic catalyst. To a great extent, evaluations of the epic were only extensions of the speaker's position vis-à-vis the social forces he or she saw the epic as representing. Only an outsider could conceive of asking for a reaction to a performance of Sìrat Banī Hiläl without understanding that the response would in fact index a set of attitudes toward social values relating to folk Islamic practice, institutional Islam, and the current revisionist movements as well as to age groups, literacy, education levels, and a host of other conflicted social issues. To understand the accrual of significance of a specific episode, or of the larger tradition, to participants, would be to understand a lengthy and complex process of lamination, layer upon layer of tales retold.

Sirat Bañ Hilal is a vast narrative tradition. It is found in many different regions of the Arab world in oral tradition and is known in its written forms even in those areas where an oral tradition does not exist or has died out. At any one site, the story of the Banī Hilāl is likely to exist simultaneously in many different forms. In the region of al-Bakātūsh itself, as I have pointed out, there are men and women who tell stories of $A b \bar{u}$ Zayd, Diyāb, and al-Zanātī Khalīfa as folktales; others in the vicinity can narrate in prose with some verse passages (recited, not sung); others read cheap "yellow-book" versions, and a handful even recite publicly from these chapbook editions; and finally, of course, 
there are the hereditary, professional epic-singers whom we have examined in some detail.

The epic has also become a potent symbol in modern Arabic (written) literature, yet it is deployed as a symbol for many different ideas. In Tayeb Salih's The Light of the House, Abū Zayd is cited as a traditional representative of manhood and virility; in Nizār al-Qabbānı̄'s Bread, Hashish and Moon, he lingers in the reader's mind as the closing image of the poem, a symbol of anachronistic heroism and outdated codes of honor and chivalry; in Naguib Mahfouz's Midaq Alley, the rabāb poet and his epic tales are a sign of an older order displaced by modernity as he is pushed out of the café and replaced by a radio in one of the opening scenes of the novel. In Mahfouz's later work, Children of Gebelawi, an allegorical novel based upon the lives of the Prophets Adam, Moses, Jesus, and Muammad, the author uses the rabāb-poet as the thread of continuity and tradition who reappears in each generation.

In Sahar Khalifeh's poignant but angry novel Wild Thorns, about life in the Occupied West Bank of Palestine, the wounded Abu Sabir begs someone to tell him an Abu Zayd story to lift his spirits as he faces the possibility of bleeding to death, but no one present can remember one; sitting at home after having lost his fingers and his livelihood, he again asks for an Abū Zayd story, but his friends cannot remember any. Finally, when Usama, recently returned from several years abroad, refuses to listen to the West Bankers' explanations of their precarious coexistence with the Israeli state, Abu Sabir concludes that Usama cannot bear to hear the truth, and bitterly adds that Usama only wants to hear nice Abū Zayd stories.

In Gamal al-Ghitani's brooding and foreboding novel about the destructive effects of absolute power, Al-Zeini Barakat, the rabāb-poets are portrayed as an extension of the Internal Security's propaganda machine; the leader of the poets' guild secretly reports to the head spy for orders about which stories to sing and how to portray the heroes-the voice of authoritarianism couched as tradition.

Our path has led from a description of the village of al-Bakātūsh and of the community of poets within al-Bakātūsh to an exploration of how those social realities occasion and help constitute the epic performance tradition. The very content of the epic reflects generations of negotiations of social status, patronage, the role of poet in the world, and images of manhood, womanhood, and honor as expressed in the portrayal of heroes and heroines, villains and saints. Finally, the examining the interactive activity of performance has led us back outward to the listeners, and to the overarching social stances and views with which they approach, evaluate, patronize, and participate in the Sìrat Banì Hilâl tradition. 